\section{Contents of this Issue}

\section{Articles}

H. Bruchertseifer, M. Constantinescu, O. Constantinescu, K. A. Gawrilov, M. Schwarzenberg, I. Zvara: Radiochemical Investigations on the Enrichment of Heavy Metals from Geothermal Sources ............ 405

B. L. Shoujkov: Separation of Some Radioactive Elements from Metallic Cyclotron Targets through Sublimation in an Air Current and Separation by Means of Chemical Selective Filters (in Russian) .........4 411

B. Gorski: On the Separation of Fission Products from the Nuclear Fuel Waste Re. processing $\ldots \ldots \ldots \ldots \ldots \ldots \ldots \ldots, 416$

N.Gorski: The Curvature Dependence of Surface Tension of the Nuclear Matter . . . 421

G. Weise, K. Wetzel, G. Stiehl: Application of the Compartment Theory to an Isotopic Geochemical Model of the Nitrogen Cycle. . 424

K. Farjo, G. Haase, W. La'ith, S. Aziz: Distribution of Deuterium in Natural Iraqi Waters (in English) ................. 431

\section{Letters to the Editor}

V. Chosnovska, E. Langrock, O. D. Maslov: Concentration of Microelements from Thermal Brines of the Cheleken Peninsula through Froth Flotation (in Russian) .... 434

B. Lorenz, K.-H. Heinrich, M. Herrmann, G. Moebius: Synthesis of Partially Deuterated Olefines. Produktion of Transstilbene- $D_{10}$ and of Pentene-(1)-4.4.5.5.5- $D_{5} \ldots \ldots \ldots 437$

Information 438

New Books 440

\section{Festkörperphysik}

\section{Von KONRAD KREHER}

(Wissenschaftliche Taschenbücher, Reihe Mathematik/Physik)

\section{Auflage}

1976. 223 Seiten - 122 Abbildungen - kl. $8^{\circ}$ $12,50 \mathrm{M}$

Bestell-Nr. 7615643 (7103)

In dem Buch werden die Grundlagen der Festkörperphysik dargestellt, d. h.) es werden Methoden erläutert, wie man die makroskopischen Eigenschaften kristalliner Festkörper aus ihrem atomaren Aufbau heraus verständlich machen bzw. berechnen kann. Dic Uberlegungen werden anhand einfacher (meist eindimensionaler) Modelle ausgeführt, wichtige Experimente im Prinzip (ohne technische Details) erläutert. Voraussetzungen zum Verständnis sind Grundlagenkenntnisse der Experimentalphysik (etwa im Umfang einer einjährigen Vorlesung) und der Quantenphysik (im wesentlichen WelleTeilchen-Dualismus und Atombau).

Bestellungen durch eine Buchhandlung erbeten

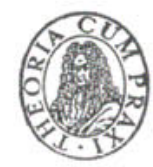

\section{AKADEMIE-VERLAG}

DDR-1086 Berlin, Leipziger Str. 3-4 